\title{
The Impact of Family Ownership on the Capital Structure of Palestinian Firms
}

\author{
Submitted 20/05/21, 1st revision 28/06/21, 2nd revision 18/07/21, accepted 10/08/21
}

\author{
Nizar Dwaikat ${ }^{1}$, Mohamed Imen Gallali ${ }^{2}$ Mohammed Saadeh ${ }^{3}$
}

\begin{abstract}
:
Purpose: This study aims to examine the impact of family ownership on the capital structure with control variables that have been found to affect the capital structure demonstrated in previous studies in the context of the Palestinian market.

Design/Methodology/Approach: Panel data (unbalanced) was used to sample non-financial firms listed in the stock exchange from 2010 to 2018. Regression with Driscoll-Kraay standard errors was used to address serial correlation and heteroscedasticity issues and possibly correlate between the groups (panels).

Findings: The findings from the T-tests showed that family firms were less leveraged, less in the concentration of ownership, and lesser in their size compared to non-family firm counterparts but were more profitable than non-family firms. Furthermore, regression analysis results showed that the impact of family ownership negatively and significantly affected debt usage in the capital structure (book value of debt). The capital structure (market value of debt) was also positively and significantly affected.

Practical Implications: Findings of the study help investors and lenders in the Palestinian market to understand how family firms behave toward employing debt in the capital structure. This may be important in the context of the Palestinian market as family ownership is considered a leading player in ownership structure.

Originality/Value: Former studies have focused majorly on the effect of ownership structure on the firm's performance. The impact of ownership structure on the capital structure received less attention in general and particularly family ownership. To our best knowledge, the current empirical research is the first to analyze the resolutions of the capital structure of family companies.
\end{abstract}

Keywords: Capital Structure, Debt, Family Firm, Ownership Concentration.

JEL Classification: G0, G5.

Research type: Research article.

\footnotetext{
${ }^{1}$ Assistant Professor and Acting Director, Business Faculty, Arab Open University Palestine Branch, Palestine. E-mail: nizar.dwaikat@aou.edu.ps;

${ }^{2}$ Manouba University, ESCT, RIM RAF UR13ES56, Tunisie, mohamedimen.gallali@esct.uma.tn;

${ }^{3}$ Ph.D., Ecole Superieure de commerce de Tunis Tunisia, Manouba University, mohamed.s.saadeh@gmail.com;
} 


\section{Introduction}

The mechanisms used by companies to select an optimal capital structure (hereafter referred to as CS) are still puzzling and one of the unresolved topics in the literature of finance since the paper by Modigliani and Miller (1958). Thus, a question was asked by Myer (1984), "How do firms choose their capital structures" is still debatable. Modigliani and Miller stated that decisions on CS are non-related to the market value of a company, which is known as the MM theory. In this theory, Modigliani and Miller relied on investors' rationale and the suppositions of the perfect and complete capital markets. Nevertheless, subsequent studies improved the realm of CS theories by considering many market imperfections. For instance, a study by Modigliani and Miller (1963) began to expand their MM-theory via the put in taxes and costs of financial distress.

From another perspective, the static trade-off theory of CS presumes that in order to arrive at an optimal state of CS, a firm should balance, at the margin, between its benefits of tax to use debts and costs of financial distress, i.e., cost of financial distress from adding one unit of debt is equal to the benefit of adding one unit of debt (tax shield). This would also mean that based on this theory, managers of a firm aim to build an optimal CS determined through a trade-off between the costs and benefits using debt.

In addition, the pecking order theory of CS is based on a dynamic viewpoint of investment chances and asymmetric information (Myers, 1984; Myers and Majluf, 1984). This theory presumes that companies favor potential funding growth with internal resources, debt, preferred stocks, and common equity, in the order stayed. The rationale view of the pecking order theory is that asymmetric information between company insiders who are informed and external investors who are uninformed leads to mispricing of issuance of equities. Thus, the resolution that managers are driven towards is via the desire to reduce the transaction costs. Despite the domination of these two models in the debate of CS theories, many scholars have suggested other determinants of CS resolutions. These determinants include the signaling perspective (Ross, 1977), aversion of risk (Fama, 1980; Masulis, 1988; Berger et al., 1997), market timing issues (Baker and Wurgler, 2002), and agency costs (Jensen, 1986).

However, in the current study, we concentrate on another primary determinant for CS resolution, the agency conflict (Jensen, 1986; Jensen and Meckling, 1976). Specifically, this study compares two distinct sets of companies considered non-equal in terms of agency conflicts, family companies and non-family companies. This was based on the prevalent supposition that agency problems are less likely to occur in family companies (Nk Dwaikat, Queiri, and Aziz, 2014), thus, it can be anticipated that there is a lower need for the role of disciplining from employing debts in such companies and that family companies have lesser leverage ratio. 
Empirical proofs on this topic are inconclusive, and most concentrate on advanced countries, such as the USA. For example, Mishra and McConaughy (1999) found that family companies in the USA employ a low debt ratio to avert a loss of control and lower the probability of bankruptcy. In contrast, the findings of Anderson and Reeb (2003b) had shown that there was no systematic variation between family and nonfamily firms in using debts in the USA. A study conducted in Germany (Ampenberger et al., 2009) found that corporate family companies have less leverage ratio than nonfamily companies. The results of studies from Italy (Gottardo and Maria Moisello, 2014) and Spain (Acedo-Ramírez, Ayala-Calvo, and Navarrete-Martínez, 2017) revealed that family companies used more debts in their CS than non-family companies. Furthermore, empirical evidence based on the international sample (Ellul, 2008) indicated that ownership of family companies as block-holding is positively related to the leverage ratio.

Furthermore, our selection of the nation of focus, Palestine, seems to offer a perfect environment for such a study since the following stylized facts distinguish it: (1) the country has various legal and institutional locations, has under-developing stock markets compared to common laws and also has advanced states (La Porta et al., 1998), (2) generally, family businesses are vertebral pillars in Palestine's economy, whereby $96 \%$ of Palestinian small-medium enterprise (SMEs) are considered family firms (Dwaikat, QUBBAJ, Araby, and Queiri, 2020), (3) there are concentrated ownership-styled firms with a vast number of family companies, even among listed firms (Nizar Dwaikat and Queiri, 2014).

Beginning from these discordant notes, it is by far not apparent whether family companies in Palestine employ debt and what variables drive their decision of CS. Thus, this study participates in the literature in many vital dimensions, firstly, to our best knowledge, the current empirical research is the first one to analyze the resolutions of CS of family companies in Palestine. This is key as Palestine varies considerably from western states in terms of ownership structure, corporate governance, institutional and legal settings, and debt tools used. In addition, the corporate governance in Palestine is different from other countries, such as western countries. Palestine's corporate governance is considered weak, and thus, the protection rights of stockholders are considered trivial and thus not well outlined. This may be substantially considering ownership concentration in large shareholders such as family ownerships (in the context of where Palestine family firms dominate) and who can expropriate the wealth of other stockholders.

Furthermore, in the situation of gathering family ownership and participating in a board of directors run, family as members of large stockholders with oversight, motivations and being simultaneously involved in company runs with the alignment of interests between managers and external stockholders, agency conflicts, the company's debt ratio is the lowest. This, as a result, underlines the significance of agency theory in family company studies (Nk Dwaikat et al., 2014). 
On this basis, this study complements recently conflicting empirical proofs on CS resolutions of family companies that are thus far considerably concentrating on the context of western nations. Secondly, this study uses a more progressive approach in terms of estimation methodology than former studies on CS resolutions within family companies. Therefore, employing a panel data model such as random or fixed effect rather than relying on pooled ordinary least square (OLS) allows the control of unobserved company heterogeneity (Ampenberger et al., 2009).

\section{Literature Review}

There are several theories to interpret CS resolutions. Among the plenty of interpretations, this study pursues one strand of literature that seems to be particularly promising in the context of family companies, focusing on agency theory.

This builds on the early work of Jensen and Meckling (1976) and Jensen (1986), in which the decisions of CS are related to the problems in the agency that arise among firms' parties, including stockholders, managers, and creditors. In this vein, the freecash-flow arguments emphasize the role of debt as one of the efficient instruments to minimize agency problems. In particular, Jensen (1986) stated that debt minimizes agency cost on free cash flow by decreasing the cash available for spending at the discretion of the firm's management. Indeed, the obligation to regularly pay interests and principal amounts is a probable method to avert undesirable managerial behaviors, such as empire building and ineffective investment options. Reducing stockholdersmanagement conflicts is referred to as the benefits of debt funding. It is a prevalent supposition that stockholders-management conflict between principal and agent is lower in family companies (Anderson and Reeb, 2004; Nk Dwaikat et al., 2014; Mishra and McConaughy, 1999). Thus, comparing family companies and counterpart non-family companies offers a promised empirical experiment to examine the effect of agency conflict on the resolutions of CS.

Therefore, it is intrinsic to differentiate between the impacts of the separate components within a family company, particularly family and family management ownership. Families, as the founders, commonly stay as large long-run stockholders, and they are capable of coping with the free-rider issue usually related to diffusion stockholder structures, i.e., "atomistic shareholders" (Grossman and Hart, 1980). In contrast to atomistic shareholders, these large stockholders obtain essential information on reasonable costs, have company-particular knowledge, and the motivations to watch a manager's actions efficaciously. Thus, efficient oversight because of family ownership is one reasonable approach to lessen agency conflicts in such companies. Another plausible method is supervisory board members. Oversight actions maybe even more efficient if the founder of a family company is institutionally engaged in the company's Monitoring (Ampenberger et al., 2009). As a result of the founding family's supervisory board engagement role, agency problems can be minimized as well. Agency problems may also be reduced by the regular engagement of family members in managing daily businesses. 
Additionally, whenever a founding family or its members manages a firm, the interests of external stockholders and managers are aligned. This alignment of interests further minimizes or even removes agency problems inside family companies. Agency problems are anticipated to be lesser if ownership of family and managing its engagement co-occur (Nk Dwaikat et al., 2014). Thus, if the owners are engaged in managing the company's daily businesses, it is anticipated that the debt ratio will be at the lowest level.

In addition to agency problems, other features of a family company may also impact the options of CS (Nk Dwaikat et al., 2014). Founding families are inclined to have long-run obligations- sometimes spanning more than one family generation, thus offering "patient capital" (James, 1999). In several cases, the family's reputation is tied to the portrait and economic success of its company. The founded families in such companies do not view the company as only a stream of cash but also an asset that will be passed on to the next generations of a family (Chami, 2001). As a result, founding families may be worried about any loss of control over the company. This may impact the resolutions of CS in two ways, on the one hand, it is a reason for families to favor using debt over equity in funding the CS in order to avert dilution of the ownership (Nk Dwaikat et al., 2014), while on the other hand, it is a reason to also avert debt due to active creditor's oversight.

Furthermore, founding families are commonly more extensive and less diversified investors. Thus, they encounter a high level of risk, with the family company is the single asset that is likely to cause a rise in risk aversion, compared with diversified investors (Nk Dwaikat et al., 2014). Apart from this, other non-financial reasons could explain why founding families want to reduce the default risk of their companies. For example, the personal benefits of founders, such as prestige or high social reputation, could be lost if the company faces financial distress or eventually becomes bankrupt (Ampenberger et al., 2009). Therefore, ownership by the family could avoid the risk and is hence anticipated to cause a lesser debt ratio in the CS of a company.

Finally, to sum up, the above discussion, it is anticipated (1) that family companies possess a lower debt ratio than non-family companies, (2) ownership of the company by the family reduces the level of debt ratio because of lowered agency problems and risk avoidance, (3) engagement of the family in managing the company lead to a reduced level of the debt ratio, in addition to alignment-of-interests-impacts and reducing agency problems. Based on these presumptions, the following hypothesis was derived:

H1: There is significant negative relationship between family ownership and leverage ratio of a company. 


\section{Research Methodology}

\subsection{Data Collection and Measurement of Variables}

Our estimation employs an unbalanced panel of 21 non-financial companies listed in the Palestine exchange between 2010-2018. Selection of the companies consisted of many steps, firstly, non-financial companies from industrial and services sectors were chosen. Financial firms differ in some aspects compared to non-financial ones, such as being heavily regulated, and financial sectors are risky as they generally rely on the depositor's money and being more leveraged than non-financial counterparts (Mehran and Mollineaux, 2012). As the traits of financial companies' reports are different from non-financial companies, financial companies were excluded from the study sample. Secondly, data availability for the sampling period was vital, thus, selected firms must not have considerably missing data. Finally, companies must not be delisted during the study period. According to a website on Palestine Exchange, it states 48 listed firms which are distributed as follows: Banks 7, Insurance 7, Investment 10, Industry 13, and Services 11. Inclusion of the stated conditions and the targeting of nonfinancial firms retained 25 firms involved in two sectors (service and industrial). Further exclusion of delisted firms and those with considerably missing data resulted in 21 companies.

\subsection{Measuring Variables}

In this study, capital structure is a dependent variable by past literature measuring CS, which used Leverage ratio as a proxy for CS (Ampenberger et al., 2009; Li and Stathis, 2017). In this study, two measures were employed for the leverage ratio, book and market value for debt ratio. The book leverage is a ratio of total liabilities to total assets, whereas the market leverage is a ratio of total debt to the market value of equity plus total debt (Li and Stathis, 2017). An important point to note is that in Palestine, there is no bonds market, while preferred stocks are rare or non-existent.

Classification of family firms: Generally, there is no official or direct disclosure for what a family can own in public firms. Therefore, disclosures in Palestine are considered weak. However, related literature in the past followed an indirect way to classify a company as a family or non-family company based on many standards (Asser, 2011; Bataineh, Abuaddous, and Alabood, 2018; Burghleh and Al-Okdeh, 2020; Heng Teh, San Ong, and Yi Ying, 2017). These criteria can be summed up as follows: a) based on what family members own in the firm, i.e., these are significant shareholders, whether these members are connected by blood, siblings, or marriage, b) participation of family members in management or their presence in the board of directors and, c) when a founder of the firm is still a CEO. For example, related studies in Jordan defined a company as a family firm when family members own at least $20 \%$ of direct and indirect ownership, or the existence of two or more members of same the family on the board of directors with at least one of them is a president or vice president of the board of directors, or the existence two or more family members in 
higher management whereby every member owns $5 \%$ or more in the ownership structure (Bataineh et al., 2018; Yasser, 2012). The current study followed a similar environment as Jordan, which has many laws and regulations similar to Palestine to classify family and non-family firms.

\subsection{Control Variables}

In our estimation, we employ a group of control factors (Table 1) reported in related literature to have an impact on the CS for publicly traded firms (Acedo-Ramírez et al., 2017; Ampenberger et al., 2009; Frank, Murray, and Goyal, 2009; Li and Stathis, 2017). These factors include firm size, profitability, growth (Tobin-Q), significant shareholders, assets utilization, and the kind of industry.

Company size is incorporated in the analysis to account for the fact that big companies have more ability to have debt as they have more creditworthiness, faceless difficulty accessing debt markets, and can borrow with less cost (Ampenberger et al., 2009). Therefore, a positive relationship between company size and debt ratio is expected. A natural logarithm of total sales was used as a measure of company size.

In general, family companies might face lower agency costs of free cash flow and rely more on insider funds, as families commonly manage and monitor the firm's activities (Nk Dwaikat et al., 2014). Additionally, according to the pecking order theory, companies favor funding new projects via retained earnings, which is often pursued using new debts, whereas issuance equity is the last choice for funding. Thus, a negative relation between the company profitability and debt ratio is expected. After interest and taxes were divided by total assets, the net income was utilized as a proxy for company profitability. Furthermore, this study controlled the company's growth options by incorporating the market-to-book ratio into the analysis. Asymmetric information could lead companies to issue stocks rather than debt if they have profitable investment options, i.e., net present value-positive projects (Myers, 1997). Moreover, a company may favor keeping profit rather than paying it as dividends if they have valuable growth prospects (Ampenberger et al., 2009). Based on this evidence, a negative relationship is expected between growth and debt ratio.

Decisions about using debt in CS of a firm, in general, rely on the company's governance structure. Thus, the current study used corporate governance tools in the analysis. Oversight through large stockholders could be an alternative corporate governance tool that reduces agency costs due to conflict between stockholders and management (Ampenberger et al., 2009). Therefore, the antagonistic relation between ownership of large stockholders and debt ratio is expected. The cumulative firm ownership of large external shareholders with an ownership stake of at least $5 \%$ in the analysis was used.

Moreover, harmonious with existing literature, agency conflicts were included as control variables. The agency theory has stated that the utilization of debt in CS 
minimizes agency costs (Jensen, 1986). Previous studies used two proxies in measuring agency costs, assets utilization ratio and discretionary expenditure. Asset utilization ratio was computed as total sales revenue divided by total assets, and discretionary expenditure was computed as annual sales, general and administrative expenditure divided by annual total revenue (Singh, Davidson, and Davidson III, 2003). This study used the asset utilization ratio because of weak disclosure in Palestine. Thus, some data and another ratio of discretionary expenditure were not easily computed. Asset utilization ratio gauges the capabilities of firm managers to employ the asset efficiently, so a higher ratio shows that a large sales size was generated for a given level of assets, while a lower ratio shows that managers of a firm are using assets in a non-cash creating and value-destroying project, as pointed out by the presence of agency conflicts (Tarus and Ayabei, 2016). It is thus anticipated that a positive relationship between agency measure and CS of firms exists.

\section{Table 1. Measurement of variables}

\begin{tabular}{|c|c|}
\hline Variables & Measurement \\
\hline \multirow{2}{*}{$\begin{array}{l}\text { Dependent } \\
\text { variable }\end{array}$} & TlibTasset is the book leverage is a ratio of total liabilities to total assets \\
\hline & $\begin{array}{l}\text { TOdebtMequity= the market leverage is a ratio of total debt to the market } \\
\text { value of equity plus total debt. }\end{array}$ \\
\hline $\begin{array}{l}\text { Independent } \\
\text { variable }\end{array}$ & $\begin{array}{l}\text { familyow is dummy one for family firm and zero for non-family firm, and } \\
\text { this based on illustration under section "Classification of family firms" }\end{array}$ \\
\hline \multirow{6}{*}{$\begin{array}{l}\text { Control } \\
\text { variables }\end{array}$} & Logsale =Natural logarithm of total sales, firm size \\
\hline & ROA $=$ net income divided by total assets, profitability \\
\hline & assetUT =total sales revenue divided by total assets, assets utilization \\
\hline & tobinQ $=$ market value of equity + total liabilities divided total assets, growth \\
\hline & $\begin{array}{l}\mathrm{COW}=\text { The cumulative firm ownership of large external shareholders with } \\
\text { an ownership stake of at least } 5 \% \text {, Large shareholders }\end{array}$ \\
\hline & Sector $=$ dummy one for industrial firms and zero for services firms \\
\hline
\end{tabular}

Source: Own creation.

\subsection{Panel Model}

The aim of current the study is to test the impact of family ownership on CS, thus a panel data model of next baseline form was used:

$$
Y i t=\beta+\mathrm{Xit}+\mathrm{Zit}+\mathrm{U} i t
$$

$\mathrm{U}$ it is errors term, $\mathrm{i}$ is individual, $\mathrm{t}$ is time, $\mathrm{B}$ is intercept, $\mathrm{X}$ is independent variable (family ownership), Zit are control factors (firm size, profitability, growth Tobin Q, asset utilization), large shareholders, as well as industry), and $\mathrm{Y}_{\mathrm{it}}$ is dependent factor (capital structure).

The Panel data method is considered the most effective statistical technique and is vastly utilized in econometrics and social science (Wellalage, Fauzi, and Wang, 2014). This method's structure considers the unobservable parameters that are consistent and 
with heterogeneity (Wooldridge, 2010). It also generates more accurate statistics, more robust statistical tests and measures the significance of non-observable individual impacts, reducing the non-attendance of pertinent factors in explaining the response factor (Matias and Serrasqueiro, 2017). Unobserved heterogeneity indicates the omission of factors that are fixed for an individual. In cross-sectional data, there is no specific reason to distinguish between ignored factors that are non-changing over time and omitted factors that are altering.

However, when an ignored factor is non-changing over time, the panel data provides another mechanism for removing the bias (Josheski, Lazarov, Fotov, and Koteski, 2011). The panel data could have individual (group) impact, time impact, or both, estimated through fixed effect and random effects models (Yaffee, 2003). In the fixed effect estimation, the object-specific impact is a random factor that is permitted to be associated with independent factors. If the omitted factors are steady over time, the panel data estimators consistently estimate the impact of the observed explanatory factors.

Furthermore, the fixed-effect model supposes that the time-varying independent factors are not entirely co-linear, that they have non-zero within-variance. This means that there are variations over time for a given object with not too many extreme values, and thus, this model cannot have steady or any time-invariant factors (Hun, 2011). While the random effect model supposes that omitted time-invariant factors are not associated with the incorporated time-varying factors, this model also fits the data of time-invariant factors. In addition, the random effect model has the advantage of greater efficiency relative to the fixed-effect model leading to lower standard errors of coefficients and higher statistical power to discover impacts (Bollen and Brand, 2010). Since the main factor in this study is the time-invariant variable (family firm), the random effect model was used to fit the data. In general, the analysis starts with the pooled panel data model (ordinary least squares, OLS), followed by fixed and random effect models. There were many tests employed to select among these models, including the F test to choose between pooled panel data and fixed effect. In contrast, the Lagrange multiplier (LM) test was conducted to choose between pooled panel data and random effects. In both tests, if the null hypothesis was not rejected, the pooled panel data was favored.

\subsection{Diagnostic Tests}

Many diagnostic tests were done in this paper to check multicollinearity, serial correlation, and heteroscedasticity tests. Firstly, the study tested for the existence of multicollinearity utilizing variance inflation factors (VIF). Multicollinearity occurs when two or more independent factors are associated, and a threshold of VIF values of 10 was proposed (Hair et al., 2006). The findings in Table 1 of the testing of multicollinearity through variance inflation factors (VIF) for every one of the factors employed in this research were within the control factors with a range from 1.7 to 1.3. This proposes the non-existence of multicollinearity. 
Furthermore, this study tested for heteroscedasticity, which is a common issue in panel studies, apart from cross-sectional dependence and serial correlation. Hence, the panel data set had problems of autocorrelation and heteroscedasticity. The panel model needs to conduct diagnostics tests, such as a Breusch and Pagan Lagrange multiplier test for random effects with the null hypothesis that the variance of the random impact is zero: $\operatorname{Var}\left[\mathrm{u}_{\mathrm{i}}\right]=0$. This would imply that each case has a similar intercept. Thus, a pooled model can be used. In this study, findings of such tests in both models (book and market value of debt) cannot be accepted as a null hypothesis but rather a random effect. The Wooldridge test for autocorrelation with the null hypothesis revealed no first-order autocorrelation. This result is shown in Table 3 and leads to the nonacceptance of the null hypothesis in both models (book and market value of debt).

Consequently, the panel model has a serial correlation. To test heteroscedasticity, the study used Panel Group-wise Heteroscedasticity Tests with the null hypothesis. The Panel Homoscedasticity findings are shown in Table 3 diagnostics tests for random panel models that null hypothesis can be rejected and panel model experiencing heteroscedasticity. Furthermore, testing cross-sectional dependence in the panel model was done by testing for weak cross-sectional dependence with null hypothesis H0: errors are weakly cross-sectional dependent (Pesaran, 2015). Based on the finding in Table 3, we cannot reject the null hypothesis. Thus, the panel model does not have cross-sectional dependence.

Table 2. Testing multicollinearity utilizing variance inflation factors (VIF).

\begin{tabular}{|l|c|c|}
\hline Variable & VIF & 1/VIF \\
\hline assetUT & 1.740 & 0.575 \\
\hline familyow & 1.650 & 0.605 \\
\hline logsale & 1.620 & 0.618 \\
\hline SCTOR & 1.510 & 0.661 \\
\hline ROA & 1.430 & 0.701 \\
\hline COW & 1.350 & 0.741 \\
\hline tobinQ & 1.310 & 0.766 \\
\hline Mean VIF & 1.510 & \\
\hline
\end{tabular}

Source: Own creation.

To deal with possible issues of contemporaneous correlations, there are many models available in the literature on heteroscedasticity and serial correlation. A popular model is the feasible generalized least squares (FGLS) model that can account for heteroscedasticity and serial correlation. FGLS is infeasible when the period is less than cross-sectional because it underestimated the coefficient of standard errors (Beck and Katz, 1995). Thus, such a model may be non-suitable in the current study. However, a regression with Driscoll-Kraay standard errors can address serial correlation and heteroscedasticity issues and possibly correlate between the groups (panels). The maxim lag for such a regression is T minus 1 . Additionally, the model can estimate the balanced and unbalanced panel data (Hoechle, 2007). Variables as identified in Table 1. 
Table 3. Diagnostics tests for panel random models

\begin{tabular}{|c|c|c|}
\hline Model-one- TlibTasset & & \\
\hline $\begin{array}{l}\text { Wooldridge test for autocorrelation in panel data } \\
\text { H0: no first-order autocorrelation }\end{array}$ & $\mathrm{F}(1,20)=7.286$ & Prob $>F=$ \\
\hline $\begin{array}{l}\text { Breusch and Pagan Lagrange multiplier test for } \\
\text { random effects } \\
\text { Test: } \operatorname{Var}(\mathrm{u})=0\end{array}$ & $\begin{array}{l}\text { chibar2 }(01)= \\
200.31\end{array}$ & $\begin{array}{l}\text { Prob }>\text { chibar } 2= \\
0.0000\end{array}$ \\
\hline $\begin{array}{l}\text { Pesaran (2015) test for weak cross-sectional } \\
\text { dependence. } \\
\text { Residuals calculated using predict, e from xtreg. } \\
\text { Unbalanced panel detected test adjusted. } \\
\text { H0: errors are weakly cross-sectional dependent. }\end{array}$ & $\mathrm{CD}=-0.713$ & $\mathrm{p}$-value $=0.476$ \\
\hline \multicolumn{3}{|c|}{$\begin{array}{l}\text { Panel Groupwise Heteroscedasticity Tests Ho: Panel Homoscedasticity- Ha: Panel Groupwise } \\
\text { Heteroscedasticity }\end{array}$} \\
\hline Lagrange Multiplier LM Test & $=1.49 \mathrm{e}+04$ & $\begin{array}{l}\text { P-Value > Chi2(20) } \\
0.0000\end{array}$ \\
\hline Likelihood Ratio LR Test & $=57.3873$ & $\begin{array}{l}\text { P-Value > Chi2(20) } \\
0.0000\end{array}$ \\
\hline Wald Test & $1.45 \mathrm{e}+05$ & $\begin{array}{l}\text { P-Value > Chi2(21) } \\
0.0000\end{array}$ \\
\hline \multicolumn{3}{|l|}{ Model-two- TOdebtMequity } \\
\hline $\begin{array}{l}\text { Wooldridge test for autocorrelation in panel data } \\
\text { H0: no first-order autocorrelation }\end{array}$ & $\begin{array}{l}\mathrm{F}(1,20)= \\
39.810\end{array}$ & Prob $>F=0.0000$ \\
\hline $\begin{array}{l}\text { Breusch and Pagan Lagrange multiplier test for } \\
\text { random effects } \\
\text { Test: } \operatorname{Var}(\mathrm{u})=0\end{array}$ & $\begin{array}{l}\text { chibar2 }(01)= \\
278.05\end{array}$ & $\begin{array}{l}\text { Prob }>\text { chibar2 }= \\
0.0000\end{array}$ \\
\hline $\begin{array}{l}\text { Pesaran (2015) test for weak cross-sectional } \\
\text { dependence. } \\
\text { Residuals calculated using predict, e from xtreg. } \\
\text { Unbalanced panel detected; test adjusted. } \\
\text { H0: errors are weakly cross-sectional dependent. }\end{array}$ & $\mathrm{CD}=-0.310$ & $\mathrm{p}$-value $=0.757$ \\
\hline \multicolumn{3}{|c|}{$\begin{array}{l}\text { Panel Groupwise Heteroscedasticity Tests Ho: Panel Homoscedasticity- Ha: Panel Groupwise } \\
\text { Heteroscedasticity }\end{array}$} \\
\hline Lagrange Multiplier LM Test & $=2.38 \mathrm{e}+04$ & $\begin{array}{c}\text { P-Value > Chi2(20) } \\
0.0000\end{array}$ \\
\hline Likelihood Ratio LR Test & $=79.9728$ & $\begin{array}{c}\text { P-Value > Chi2(20) } \\
0.0000\end{array}$ \\
\hline Wald Test & $=2.95 \mathrm{e}+05$ & $\begin{array}{c}\text { P-Value > Chi2(21) } \\
0.0000\end{array}$ \\
\hline
\end{tabular}

Source: Own creation.

\section{Data Analysis}

\subsection{Descriptive Statistics}

Table 3 above showed that Palestinian firms incorporated as samples in this study employed debt at an average of $32 \%$ as a book value of debt and $15.8 \%$ on average as a market value. For the size of Palestinian firms in terms of the natural logarithm, total average sales of 15.84 were obtained. In addition, an average concentration of ownership was $54.9 \%$, whereby these firms owned $5 \%$ and above. The average of 
Tobin Q as a measure of growth was 1.051, while the mean of Palestinian firms' performance in terms of net income to total assets was 3.3\%. The mean of assets utilization for the firms of this study was $47.2 \%$

Table 4. Descriptive Statistics for all factor included in the study

\begin{tabular}{|l|r|r|r|r|r|}
\hline Variable & Obs & Mean & Std. Dev. & Min & Max \\
\hline TOdebtMequity & 179 & .158 & .194 & 0 & .686 \\
\hline TlibTasset & 179 & .323 & .184 & .025 & .751 \\
\hline Logsale & 179 & 15.844 & 1.741 & 11 & 20 \\
\hline COW & 178 & .549 & .274 & 0 & .93 \\
\hline tobinQ & 179 & 1.051 & .357 & .28 & 2.411 \\
\hline ROA & 179 & .033 & .092 & -.622 & .261 \\
\hline assetUT & 179 & .472 & .338 & .02 & 1.95 \\
\hline
\end{tabular}

Source: Own creation.

Table 5. Frequency for dummies factors

\begin{tabular}{|l|r|r|r|}
\hline SCTOR & Frequency & Percent & Cumulative \\
\hline Industry & 97 & 54.19 & 54.19 \\
\hline Services & 82 & 45.81 & 100.00 \\
\hline Total & 179 & 100.00 & \\
\hline familyow & Frequency & Percent & Cumulative. \\
\hline Non-Family & 109 & 60.89 & 60.89 \\
\hline Family & 70 & 39.11 & 100.00 \\
\hline Total & 179 & 100.00 & \\
\hline
\end{tabular}

Source: Own creation.

Variables as identified in Table 1. The frequency Table showed that the samples of study included 97 firms in the industry sectors and 82 companies in the services sectors (a total of 179 firms). Of these firms, family firms consisted of 170 companies and 109 companies were of nonfamily firms.

Table 6. Descriptive statistics for all factors included in the study by family and nonfamily firms.

\begin{tabular}{|c|c|c|c|c|c|}
\hline familyow = non-Family \\
\hline Variable & Obs & Mean & Std.Dev. & Min & Max \\
\hline TOdebtMequ $\sim$ y & 109 & 0.197 & 0.207 & 0 & 0.686 \\
\hline TlibTasset & 109 & 0.375 & 0.185 & 0.036 & 0.751 \\
\hline Logsale & 109 & 16.037 & 1.856 & 11 & 20 \\
\hline COW & 109 & 0.628 & 0.250 & 0 & .931 \\
\hline tobinQ & 109 & 1.023 & 0.365 & 0.280 & 2.411 \\
\hline ROA & 109 & 0.007 & 0.095 & -0.622 & 0.158 \\
\hline assetUT & 109 & .45 & 0.252 & .02 & 1.040 \\
\hline familyow = Family & Obs & Mean & Std.Dev. & Min & Max \\
\hline Variable & 70 & 0.098 & 0.155 & 0 & 0.590 \\
\hline TOdebtMequ y & 70.639 \\
\hline TlibTasset & 70 & 0.242 & 0.151 & 0.025 & 0.639 \\
\hline Logsale & 70 & 15.543 & 1.510 & 13 & 18 \\
\hline
\end{tabular}




\begin{tabular}{|c|c|c|c|c|c|}
\hline COW & 69 & 0.423 & 0.266 & .06 & .9 \\
\hline tobinQ & 70 & 1.095 & 0.343 & 0.497 & 1.978 \\
\hline ROA & 70 & 0.073 & 0.070 & -0.065 & 0.261 \\
\hline assetUT & 70 & 0.506 & 0.439 & .03 & 1.950 \\
\hline
\end{tabular}

\section{Source: Own creation.}

Table 6 provides the descriptive statistics for the included factors in this study for family and non-family firms. The analysis revealed that family firms used less debt in average in terms of book and market value of debt in their capital structure compared to non-family counterpart firms. Family firms employed in average, 9.8\% and $24.2 \%$ book and market value of debt, whereas mean of book and market value of debt in non-family firms were $19.7 \%$ and $37.5 \%$, respectively. In term of size measured by natural logarithm of total mean sales, family firms were at 15.543 and the average of non-family firms was 19.037, a number higher than family firms. The mean of ownership concentration in non-family companies was $62.8 \%$ and average of family companies was $42.3 \%$, therefore family firms were less concentrated. Looking for the mean (1.023) of Tobin-Q of non-family firms, it seems that the mean was less than family firms (1.093). It can thus be stated that family companies are in the growth phase. Moreover, the family firms were doing better in profitability and assets utilization than the non-family counterparts.

Table 7. T-test for Equality of Means for all factors included in the study by family and non-family firms

\begin{tabular}{|l|l|r|r|r|r|}
\hline familyow & N & \multicolumn{1}{c|}{ Mean } & $\begin{array}{c}\text { Mean } \\
\text { Difference }\end{array}$ & Sig. (2-tailed) \\
\hline tobinQ & Family & 70 & 1.0948 & 0.07165 & 0.19126 \\
\hline & Non-Family & 109 & 1.0232 & & \\
\hline ROA & Family & 70 & 0.0731 & 0.06610 & $0.00000^{* * *}$ \\
\hline COW & Non-Family & 109 & 0.0070 & & \\
\hline & Family & 69 & 0.4235 & -0.20478 & $0.00000^{* * *}$ \\
\hline TlibTasset & Non-Family & 109 & 0.6283 & & \\
\hline & Family & 70 & 0.2424 & -0.13245 & $0.00000^{* * *}$ \\
\hline TOdebtMequity & Non-Family & 109 & 0.3748 & & \\
\hline & Family & 70 & 0.0983 & -0.09873 & $0.00076^{* * *}$ \\
\hline Logsale & Non-Family & 109 & 0.1970 & & \\
\hline & Family & 70 & 15.5429 & -0.49384 & $0.06389^{*}$ \\
\hline assetUT & Non-Family & 109 & 16.0367 & & \\
\hline & Family & 70 & 0.5059 & 0.05586 & 0.28117 \\
\hline$* * * p<.01, * *$ \\
$p<.05, * p<.1$ & Non-Family & 109 & 0.4500 & & \\
\hline
\end{tabular}

Source: Own creation.

Table 7 above shows the mean difference between family and non-family firms for all factors included in this study. From Table 7, there are no statistically significant differences between family and non-family firms in terms of growth chances, as measured by Tobin-Q and assets utilization. At the same time, the differences between family and non-family firms were statistically significant in terms of using debt in 
both measures of book and market value, profitability (ROA), ownership concentration, and size, as gauged by the natural logarithm of total sales. This meant that family firms are less leveraged, concentrated in ownership, and smaller in size compared to non-family firms but are more profitable.

Table 8. Matrix of correlations for all factors included in the study by the year of study

\begin{tabular}{|c|c|c|c|c|c|c|c|}
\hline Variables & $(1)$ & (2) & (3) & (4) & $(5)$ & (6) & (7) \\
\hline $\begin{array}{l}\text { (1) } \\
\text { TOdebtMequity }\end{array}$ & 1.000 & & & & & & \\
\hline (2) familyow & -0.245 & 1.000 & & & & & \\
\hline (3) logsale & 0.116 & -0.132 & 1.000 & & & & \\
\hline (4) COW & 0.191 & -0.365 & -0.091 & 1.000 & & & \\
\hline (5) tobinQ & -0.327 & 0.110 & 0.226 & 0.203 & 1.000 & & \\
\hline (6) $\mathrm{ROA}$ & -0.552 & 0.355 & 0.279 & -0.091 & 0.357 & 1.000 & \\
\hline (7) assetUT & 0.185 & 0.082 & 0.453 & -0.204 & 0.005 & 0.118 & 1.000 \\
\hline Variables & (1) & \begin{tabular}{l|l}
$(2)$ \\
\end{tabular} & (3) & (4) & (5) & (6) & (7) \\
\hline (1) TlibTasset & 1.000 & & & & & & \\
\hline (2) familyow & -0.347 & 1.000 & & & & & \\
\hline (3) logsale & 0.258 & -0.132 & 1.000 & & & & \\
\hline (4) $\mathrm{COW}$ & 0.052 & -0.365 & -0.091 & 1.000 & & & \\
\hline (5) tobinQ & 0.195 & 0.110 & 0.226 & 0.203 & 1.000 & & \\
\hline (6) $\mathrm{ROA}$ & -0.402 & 0.355 & 0.279 & -0.091 & 0.357 & 1.000 & \\
\hline (7) assetUT & 0.244 & 0.082 & 0.453 & -0.204 & 0.005 & 0.118 & 1.000 \\
\hline
\end{tabular}

Source: Own creation.

Table 8 of Matrix of correlations shows the association between debt ratio measures in the capital structure of Palestinian firms (book and market value of debt) and the factors included in this study. The above Table shows the negative correlation between family firms and debt ratio in both measures (book and market value of debt). The profitability (ROA) also correlated negatively with the debt ratio in both measures (book and market value of debt). While the size of firms was gauged by the natural logarithm of total sales, ownership concentration, and assets utilization as positively correlated with the debt ratio in both measures (book and market value of debt). For the correlation between growth chances as measured by Tobin-Q and book value of debt, there was a positive correlation, and on the other hand, growth chances as measured by Tobin-Q were negatively associated with the market value of debt.

\subsection{Regression Analysis}

Table 9 of regression analysis shows that R-squared in the Driscoll-Kraay model was about $50 \%$. Thus, the included independent factors explained about $50 \%$ of the variation in the dependent variable. Table 9 shows that the impact of family ownership on the capital structure (book value of debt) is negative and statistically significant. While the effect of family ownership on the capital structure (market value of debt) is positive and statistically significant. For the results of the control variables, the regression analysis Table 9 shows that the size of the firm (natural logarithm of total 
sales) had a positive and statistically significant effect on the capital structure (book and market value of debt). According to the findings of the regression analysis Table 9, ownership concentration shows that there is a negative and statistically significant impact on the capital structure (book value of debt). At the same time, ownership concentration has a positive and statistically significant effect on the capital structure (market value of debt).

Table 9. Regression analysis

\begin{tabular}{|c|c|c|}
\hline \multirow{2}{*}{ Variables } & $\begin{array}{c}\text { TlibTasset } \\
\text { Driscoll-Kraay }\end{array}$ & $\begin{array}{c}\text { TOdebtMequity } \\
\text { Driscoll-Kraay }\end{array}$ \\
\cline { 2 - 3 } & Coefficient & Coefficient \\
\hline familyow & $-0.053(-3.740)^{* *}$ & $0.035(9.93)^{* * *}$ \\
\hline logsale & $0.015(3.620)^{* *}$ & $0.037(12.75)^{* * *}$ \\
\hline COW & $-0.049(-4.620)^{* *}$ & $0.199(13.84)^{* * *}$ \\
\hline tobinQ & $0.190(36.50)^{* * *}$ & $-0.137(-11.00)^{* * *}$ \\
\hline ROA & $-1.093(-16.86)^{* * *}$ & $-1.258(13.84)^{* * *}$ \\
\hline assetUT & $0.199(7.61)^{* * *}$ & $0.057(1.90)^{*}$ \\
\hline Constant & $-0.179(-5.07)^{* *}$ & $-0.357(-11.52)^{* * *}$ \\
\hline SECTOR & Yes & Yes \\
\hline Year & Yes & 0.5130 \\
\hline R-squared & 0.5317 & $3747.03 * * *$ \\
\hline F-test & $1488.57 * * *$ & \\
\hline$* * * p<.01, * * p<.05$, & & \\
$* p<.1$ & & \\
\hline
\end{tabular}

Source: Own creation.

Moreover, growth chances (Tobin-Q) were found to positively impact the capital structure (book value of debt), and it is statistically significant. At the same time, the growth opportunities have a negative and statistically significant effect on the capital structure (market value of debt). The impact of profitability (ROA, return on assets) in the regression analysis table seems to have adverse and statistically significant effects on the capital structure (book value of debt). Finally, according to the findings of the table of regression analysis, assets utilization was found to have a positive impact on the capital structure (book and market value of debt) and is statistically significant.

\section{Results and Discussions}

Regression analysis showed that family had a negative and statistically significant impact on using debt in the capital structure (book value of debt), while it had a positive and statistically significant impact on the capital structure (market value of debt). Those findings are in line with former studies. For example, (Ampenberger et al., 2009; Tarus and Ayabei, 2016) reported a negative relationship between family ownership and using debt (Ellul, 2008; Gottardo and Moisello, 2014), for example, Ellui (2008) reported a positive relationship between family ownership and using debt. 
The negative impact could be possibly explained in the context of the risk aversion hypothesis, whereby families do not like to use debt due to failing to repay for the debtholder that may lead to bankruptcy. This is very important when the main concern is to pass a firm to the next generation of the family. Thus, such a firm may favor relying on the internal fund as it is a less risky choice (Nk Dwaikat et al., 2014). Furthermore, looking at the findings from the viewpoint of agency theory and particularly mentoring hypothesis, family as a more prominent shareholder is active in the oversight of the manager's action; thus, using debt as a substitute tool for reducing agency cost may become a lesser need, as proposed by Jensen (1986). The positive impact of families on using debt in their CS could explain the control motivations hypothesis, whereby families prefer to use debt as they would not need to issue new equity, which may lead to loss of control on the substantial dilution of shares.

Thus, debt may be a good choice after the internal found to finance a new project. They are additionally interpreting this in the context of agency cost theory, were using debt as a substitute tool for control, particularly in light of weak corporate governance environment like Palestine. In other words, families as significant stockholders may behave like institutional block-holder and use indirect tools to control the misconduct of management, thus, an increased debt to keep and improve control (Ellul, 2008). In the light of resources independence theory, the family has its network, thus making it easier to access the sources of the funds for the families to increase their debt.

The firm's size was found to have a positive effect on the leverage, as gauged by sales, and these findings are in line with Al-najjar (2011), and Migliori, Maturo, and Paolone (2018). This could be the scenario as sales rise, the need for cash also increases particularly, and if the firms are not good at collecting cash, this may resort to using debts to fund their needs. The positive impact of the firm's size on using debt in CS could be seen in the context of transaction cost theory. Here, it was pointed out that big companies tend to be more diversified and have more assets as guarantees to loans, thus, are more ready to access fund sources (Al-Najjar, 2011). The current results showed that asset utilization inversely measures agency conflicts) has a positive and significant effect on the debt, consistent with previous studies (Migliori et al., 2018; Tarus and Ayabei, 2016). Moreover, these findings could be interpreted in line with that risk-efficiency argument which states that an efficient company (common agency problems) has a lower risk of bankruptcy and financial distress, thus, tend to select rise the debt ratio (Migliori et al., 2018). Increasing agency problems also lead to rising debt ratio as an indirect tool of oversight misbehave of management (Tarus and Ayabei, 2016).

In addition, an analysis showed that profitability negatively impacted the usage of debt, which was in line with previous research (Al-najjar, 2011; Ampenberger et al., 2009; Frank, Murray, and Goyal, 2009). Furthermore, this result is in line with a pecking order theory whereby a more profitable company favors relying on internal funds as it costs less and is a less risky source instead of using debt (Myers, 1984). 
For growth chances found in the analysis to have a negative and significant effect on CS (market value of debt), the findings align (Al-najjar, 2011; Ampenberger et al., 2009; Ellul, 2008). The data was also in line with agency costs theory, whereby a company with high growth chances will be inclined to have associated agency issues because of their flexibility in future alternative investment chances (Titman and Wessels, 1988). Therefore, increasing agency problems lead to a rising debt ratio, an indirect tool of oversight misbehaves of management (Jensen, 1986). The analysis found that growth chances have a positive and statistically significant impact on CS (book value of debt), which is in line with (Al-Najjar, 2011; Kouki, 2012). This finding can be explained by the fact that Palestinian firms with good growth tend to depend on debt to fund their investment chances rather than issue new equity. The concentrated ownership structure brings this on; thus, large shareholders (e.g., family owners) are influential in decision-making using debt to keep their control on the firm when debt is a more cost-effective source than issuing equity, which is also liable to tax. Another interpreting factor is that such companies have fewer chances of financial distress and thus face more minor challenges to use the debt fund than companies with slower growth.

Finally, the current findings showed that ownership concentration has a negative and significant impact on CS (book value of debt), which corresponds to a study (Ampenberger, 2009). The finding is also in line with a mentoring hypothesis (agency theory), which states that a large stockholder is active and promising in oversight management behaviors, which creates the need to using debt and is an alternative device for external oversight, creating less needs to reduce agency costs (Jensen, 1986). The positive impact of ownership concentration on the capital structure (market value of debt) can also be interpreted as consistent agency costs where large stockholders tend to use the firm's funds for their interests (second kind of agency cost between minority and large stockholders). This action causes large stockholders to expropriate the wealth of small shareholders; thus, employing debt could be an alternative device for external oversight, reducing the need to reduce agency costs (Jensen and Meckling, 1976). this is a reasonable approach in an environment such as Palestine, where ownership structure is highly concentrated (Nizar Dwaikat and Queiri, 2014).

\section{Conclusion}

In the current study, the panel data was studied for publicly listed Palestinian nonfinancial companies (industrial and services sectors) from 2010 to 2018. To examine the impact of family ownership on debt utilization in the CS with control factors (growth, profitability, size of firm, ownership concentration, and asset utilization), it was found that this parameter affected the CS. This was in line with findings from former studies. Moreover, this study used the panel data model (Driscoll-Kraay) to analyze the data. Findings of T-tests showed that family firms are lesser leveraged, lesser in a concentration of ownership, and lesser in their size but are more profitable 
compared to non-family firms. In terms of assets utilization, there is no statistically significant between family and non-family firms.

Our significant regression analysis results showed that the impact of family ownership negatively and significantly affects the usage of debt in CS (book value of debt) and positively and significantly impacts CS (market value of debt). The negative impact could be possibly explained in the context of the risk aversion hypothesis, agency theory, and particular mentoring hypothesis. At the same time, the positive impact of family on debt utilization in their CS agreed with the control motivations hypothesis.

The findings of the size of firm control were found to positively affect the leverage in line with the transaction cost theory. The results showed that asset utilization (asset utilization inversely measures agency conflicts) affects debt usage positively and significantly. This is in line with a risk-efficiency argument, which pointed out that an efficient company (common agency problems) has a lower risk of bankruptcy and financial distress, leading to a rise in the debt ratio. While profitability negatively impacted the use of debt, it agreed with the pecking order theory whereby more profitable companies favor relying on internal funds. Growth changes were found in the analysis to have a negative and significant effect on CS, consistent with agency theory, whereby companies with high growth chances will be inclined to have associated agency issues. This leads to increasing agency problems that further lead to rising debt ratio as an indirect tool of oversight of misbehaving of the management. Lastly, the finding showed that ownership concentration has a negative and significant impact on CS, which is in line with the mentoring hypothesis (agency theory).

\section{Future Studies and Limitations of the Study}

This study has some limitations that may be considered for future studies. Firstly, it only considered family ownership, but other elements of ownership structure could be examined in the future. These include institutional and managerial ownerships to evaluate the effect of family ownership on forming CS in light of other elements of ownership structure. Secondly, the board of directors could also be examined as corporate governance tools with family-owned firms and how this affects forming CS. Finally, examining family ownership and its impact on forming CS in other sectors in the Palestinian market could be investigated.

\section{References:}

Acedo-Ramírez, M.A., Ayala-Calvo, J.C., Navarrete-Martínez, E. 2017. Determinants of capital structure: Family businesses versus non-family firms. Finance a Uver Czech. Journal of Economics and Finance, 67(2), 80-103.

Al-Najjar, B. 2011. Revisiting the capital-structure puzzle: UK evidence. The Journal of Risk Finance, 12(4), 329-338. https://doi.org/10.1108/15265941111158505.

Ampenberger, M., Schmid, T., Achleitner, A.K., Kaserer, C. 2009. Capital structure decisions in family firms: empirical evidence from a bank-based economy Working. In: No. 2009-05, Technische Universität München, Center for 
Entrepreneurial and Financial Studies (CEFS), München. Retrieved from: http://ssrn.com/abstract=1364153.

Anderson, R.C., Reeb, D.M. 2003. Founding-family ownership, corporate diversification, and firm leverage. Journal of Law and Economics, 46(2), 653-684. https://doi.org/10.1086/377115.

Anderson, R.C., Reeb, D.M. 2004. Board Composition: Balancing Family Influence in S \& P 500 Firms. Administrative Science Quarterly, 49(2), 209. https://doi.org/10.2307/4131472.

Asser, Q.R. 2011. Corporate governance and firm performance: An analysis of family and non-Family controlled firms. Pakistan Development Review, 50(1), 47-62. https://doi.org/10.30541/v50i1.

Baltagi, B.H., Jung, B.C., Song, S.H. 2010. Testing for heteroskedasticity and serial correlation in a random effects panel data model. Journal of Econometrics, 154. https://doi.org/10.1016/j.jeconom.2009.04.009.

Bataineh, H., Abuaddous, M., Alabood, E. 2018. The effect of family ownership and board characteristics on earnings management: Evidence from Jordan. Academy of Accounting and Financial Studies Journal, 22(4), 2635.

Beck, N., Katz, J.N. 1995. What to do (and not to do) with Time-Series Cross-Section Data. The American Political Science Review, 89, 3. https://doi.org/https://doi.org/10.2307/2082979.

Bollen, K.A., Brand, J.E. 2010. A general panel model with random and fixed effects: A structural equations approach. Social Forces, 89(1), 1-34. https://doi.org/10.1353/sof.2010.0072.

Burghleh, M.M.K., Al-Okdeh, S.K. 2020. The impact of family ownership concentration on the relationship between the characteristics of board of directors and earnings management. Management Science Letters, 10(5), 969-978. https://doi.org/10.5267/j.msl.2019.11.014.

Chami, R. 2001. What is Different About Family Businesses. International Monetary Fund, 1-70. https://doi.org/10.1017/CBO9781107415324.004.

Dwaikat, N., Queiri, A. 2014. The Relationship between Ownership Structure and Firm's Performance: An Empirical Evidence from Palestine. International Journal of Business and Management, 9(12), 49-61. https://doi.org/10.5539/ijbm.v9n12p49.

Dwaikat, N., Queiri, A., Aziz, M. 2014. Capital Structure of Family Companies. International Conference on Business, Law and Corporate Social Responsibility, 127-132. https://doi.org/http://dx.doi.org/10.15242/ICEHM.ED1014047.

Dwaikatt, N., Qubbaj, I., Araby, M., Queiri, A. 2020. Corporate Governance in the Small and Medium Enterprises ( SMEs ) as Performance Enhancer. In: Soliman, K.S. (Ed.). International Business Information Management Association (IBIMA). Seville, Spain: Education Excellence and Innovation Management: A 2025 Vision to Sustain Economic Development during Global Challenges.

Ellul, A. 2008. Control Motivations and Capital Structure Decisions. SSRN Electronic Journal, 1-48. https://doi.org/10.2139/ssrn.1364661.

Frank, M.Z., Goyal, V.K. 2009. Capital Structure Decisions: Which Factors are Reliably Important? Financial Management, 38(1), 68.

Gottardo, P., Maria Moisello, A. 2014. The capital structure choices of family firms: Evidence from Italian medium-large unlisted firms. Managerial Finance, 40(3), 254-275. https://doi.org/10.1108/MF-03-2013-0065.

Grossman, S.J., Hart, O.D. 1980. Takeover Bids, The Free-Rider Problem, and the Theory of the Corporation. The Bell Journal of Economics, 11(1), 42. 
https://doi.org/10.2307/3003400.

Hair, J.F., Black, W.C., Babin, B.J., Anderson, R.E. 2006. Multivariate Data Analysis. https://doi.org/10.1038/259433b0.

Heng Teh, B., San Ong, T., Yi Ying, L. 2017. Earnings Management in Malaysian Public Listed Family Firms. Jurnal Pengurusan, 51, 183-193. https://doi.org/10.17576/pengurusan-2017-51-16.

Hoechle, D. 2007. Robust standard errors for panel regressions with cross-sectional dependence. Stata Journal, 7(3), 281-312.

Hun, M.P. 2011. Practical Guides To Panel Data Modeling: A Step by Step. Public Management and Public Analysis Program, 1-53.

James, H. 1999. Owner as manager, extended horizons and the family firm. International Journal of the Economics of Business, 6(1), 41-55. https://doi.org/10.1016/j.jaci.2012.05.050.

Jensen, M.C. 1986. Agency Costs of Free Cash Flow, Corporate Finance, and Takeovers. American Economic Review, 76(2), 323-329. https://doi.org/10.2139/ssrn.99580.

Jensen, M.C., Meckling, W.H. 1976. Theory of the Firm: Managerial Behavior, Agency Costs and Ownership Structure Theory of the Firm Managerial Behavior, Agency Costs and Ownership Structure. Journal of Financial Economics, 3(4), 305-360. https://doi.org/http://dx.doi.org/10.1016/0304-405X(76)90026-X.

Josheski, D., Lazarov, D., Fotov, R., Koteski, C. 2011. Institutions and Growth revisited: OLS, 2SLS, G2SLS Random effects IV regression and Panel Fixed (within) IV regression with cross-country data. Munich Personal RePEc . MPRA Paper No. 33842, (21465). https://doi.org/10.3109/15368378209040332.

Kouki, M. 2012. Capital Structure Determinants: New Evidence from French Panel. International Journal of Business and Management, 7(1). https://doi.org/10.5539/ijbm.v7n1p214.

La Porta, R., Lopez-de-SIlanes, F., Shleifer, A., Vishny, R.W. 1998. Law and Finance Rafael La Porta , Florencio Lopez-de-Silanes. Journal of Political Economy, 106(6), 11131-11155. https://doi.org/10.1086/250042.

Li, H., Stathis, P. 2017. Determinants of capital structure in Australia: an analysis of important factors. Managerial Finance, 43(8), 881-897. https://doi.org/10.1108/MF-02-2017-0030.

Matias, F., Serrasqueiro, Z. 2017. Are there reliable determinant factors of capital structure decisions? Empirical study of SMEs in different regions of Portugal. Research in International Business and Finance, 40, 19-33. https://doi.org/10.1016/j.ribaf.2016.09.014.

Mehran, H., Mollineaux, L. 2012. Corporate governance of financial institutions: A survey. Annual Review of Financial Economics, 4, 215-232. https://doi.org/10.1146/annurev-financial-110311-101821.

Migliori, S., Maturo, F., Paolone, F. 2018. Capital Structure Determinants in Family Firms : An Empirical Analysis in Context of Crisis. International Business Research, 11(4), 65-83. https://doi.org/10.5539/ibr.v11n4p65.

Mishra, C.S., McConaughy, D.L. 1999. Founding family control and capital structure: The risk of loss of control and the aversion to debt. Entrepreneurship: Theory \& Practice, 53-64.

Myers, S. 1984. The Capital Structure Puzzle. The Journal of Finance, 39(3), 574-592. https://doi.org/10.1111/j.1540-6261.1984.tb03646.x.

Myers, S.C. 1997. Determinantes pf Coprporate browwing. Journal of Financial Economics, 5(2), 147-175. 
Myers, S.C., Majluf, N.S. 1984. Corporate financing and investment decisions when firms have information that investors do not have. Journal of Financial Economics, 13, 187-221. https://doi.org/10.1016/0304-405X(84)90023-0.

Pesaran, M.H. 2015. Testing Weak Cross-Sectional Dependence in Large Panels. Econometric Reviews, 34(10-6). https://doi.org/https://doi.org/10.1080/07474938.2014.956623.

Ross, S. 1977. The Determination of Financial Structure: The Incentive Signalling Approach. Bell Journal of Economics, 8(1), 23-40. https://doi.org/10.2307/3003485.

Singh, M., Davidson, W.N., Davidson III, W.N. 2003. Agency costs, ownership structure and corporate governance mechanisms. Journal of Banking \& Finance, 27(5), 793816. https://doi.org/10.1016/S0378-4266(01)00260-6.

Tarus, D.K., Ayabei, E. 2016. Board composition and capital structure: evidence from Kenya. Management Research Review, 39(9), 1056-1079. https://doi.org/10.1108/MRR-01-2015-0019.

Titman, S., Wessels, R. 1988. The Determinants of Capital Structure Choice. The Journal of Finance, 43(1), 1-19. https://doi.org/https://doi.org/10.1111/j.15406261.1988.tb02585.x.

Wellalage, N., Fauzi, F., Wang, G. 2014. Corporate governance and cash dividend policy: Evidence from Chinese IPOs. Management \& Accounting Review (MAR), 13(1), $1-24$.

Wintoki, M.B., Linck, J.S., Netter, J.M. 2012. Endogeneity and the dynamics of internal corporate governance. Journal of Financial Economics, 105, 581-606.

Wooldridge, J. 2010. Econometric Analysis of Cross Section and Panel Data. https://doi.org/10.1515/humr.2003.021.

Yaffee, R. 2003. A primer for panel data analysis. Connect Information Technology at NYU, 1-11. Retrieved from: papers2://publication/uuid/811319C1-BFB6-43F6-B72965AC1FA20A4D.

Yasser, Q.R. 2012. Affects of Female Directors on Firms Performance in Pakistan. Modern Economy, 03(07), 817-825. https://doi.org/10.4236/me.2012.37104. 